\title{
Patofisiologi dan Tatalaksana Osteochondral Lesion of the Talus
}

\author{
Pathophysiology and treatment of Osteochondral Lesion of the Talus \\ Maghrizal Roychan ${ }^{1}$, Andre Triadi Desnantyo ${ }^{2}$ \\ ${ }^{1}$ Residen Ortopedi dan Traumatologi, Fakultas Kedokteran Universitas Airlangga / RSUD.Dr Soetomo Surabaya \\ ${ }^{2}$ Staf Ortopedi dan Traumatologi, Fakultas Kedokteran Universitas Airlangga / RSUD.Dr Soetomo Surabaya \\ *Penulis Korespondensi: Maghrizal Roychan. Email: rizal_kun@yahoomail.com
}

\begin{abstract}
ABSTRAK
Latar Belakang: Penyakit Osteochondral Lesion of the Talus (OLT) adalah kelainan pada tulang talus di lapisan subchondral yang berupa lesi osteochondral pada talar dome dengan konsekuensi abnormalitas pada tulang rawan sendi talar. Review artikel bertujuan menjabarkan patofisiologi dan tatalaksana OLT.

Metode: Review artikel menggunakan literatur terkini yang relevan dengan topik OLT.

Hasil: Pasien biasanya datang berobat ke tenaga kesehatan dengan keluhan yang tidak spesifik dan dengan gejala seperti nyeri pada pergelangan kaki, bengkak serta berkurangnya berkurangnya ruang gerak (range of movement). Penegakan diagnosis bisa dilakukan dengan anamnesis, pemeriksaan fisik dan pemeriksaan penunjang sederhana seperti foto X-ray maupun pemeriksaan penunjang canggih seperti CT-Scan dan MRI. Tatalaksana pada OLT tergantung dari tahapan lesi, kronisitasnya, dan keluhan simtomatis yang menyertainya. Pasien dengan keluhan simtomatis yang akut dan nondisplaced sering diberikan terapi konservatif dengan imobilisasi. Lesi yang tidak berhasil atau tidak menunjukkan perbaikan keluhan setelah 3 sampai 6 bulan, serta lesi dengan displacement dapat direncanakan untuk terapi operatif. Ada beberapa macam tehnik operatif yang dapat dilakukan untuk menyembuhkan OLT. Teknik operatif ini dapat dikategorikan menjadi cartilage repair, cartilage regeneration dan cartilage replacement techniques.

Kesimpulan: OLT adalah lesiosteocondral pada talar dome yang dapat diterapi dengan terapi konservatif dan operatif cartilage repair, cartilage regeneration dan cartilage replacement techniques.
\end{abstract}

Kata kunci: osteochondral lesion of the talus, patofisiologi, tatalaksana.

\begin{abstract}
Background: Osteochondral Lesion of the Talus (OLT) is an abnormality in the talus bone in the subchondral layer in the form of osteochondral lesions in the talar dome with consequent abnormalities in the talar joint cartilage.This review wasa aimed to explain the pathophisiology and OLT management.

Method: The litheratur review used recent literature suitable with OLT topics.

Results: Patients usually come to a health care provider with nonspecific complaints and with symptoms such as pain in the ankles, swelling and reduced range of movement. The diagnosis can be made with a history taking, physical examination and simple investigations such as X-rays and sophisticated investigations such as CT-Scan and MRI. The management of OLT depends on the stage of the lesion, its chronicity, and the accompanying symptomatic complaints. Patients with acute and non-displaced symptomatic complaints are often given conservative therapy with immobilization. Lesions that are unsuccessful or show no improvement in symptomatic complaints after 3 to 6 months and lesions with displacement can be planned for operative therapy. There are several types of operative techniques that can be done to cure OLT. These operative techniques can be categorized into cartilage repair, cartilage regeneration, and cartilage replacement techniques.
\end{abstract}

Conclusion: OLT is osteocondral lesion at talar dome can be managed by conservative operalive such as cartilage repair, cartilage regeneration dan cartilage replacement techniques.

Keywords: osteochondral lesion of the talus, pathophysiology, treatment 


\section{PENDAHULUAN}

Penyakit Osteochondral Lesion of the Talus (OLT) adalah kelainan pada tulang talus di lapisan subchondral yang berupa lesi osteochondral pada talar dome. Lesi tersebut dapat menyebabkan abnormalitas pada tulang rawan sendi talar. ${ }^{1}$ OLT disebut juga sebagai Osteochondritis dissecans (OCD). Secara anatomis, talus adalah tulang sendi ketiga yang paling sering mengalami lesi setelah sendi lutut dan sendi siku. Berdasarkan literatur, angka kejadian OLT adalah $0,09 \%$ dan prevalensi 0,002/ 100.000 orang per tahun di Amerika. Angka kejadian OLT paling sering terjadi pada dekade kedua kehidupan, meskipun manifestasi klinisnya dapat muncul di usia yang lebih tua. ${ }^{2}$ Talus terletak di lokasi yang strategis, yakni pada kompleks sendi pergelangan kaki. Talus memiliki peran penting dalam distribusi gaya tekanan berat badan. ${ }^{3}$

Penyebab dari OLT masih menjadi perdebatan. Etiologi yang paling dipercaya adalah trauma mikro yang terjadi secara berulang dan adanya gangguan pada vaskular. Hal tersebut menyebabkan keluhan nyeri pada ankle yang bersifat progresif dan disertai dengan immaturitas disfungsi tulang tertutama pada usia dewasa muda. Berdasarkan laporan yang ada, $85 \%$ pasien OLT disebabkan oleh riwayat trauma. Bagian anatomis talus yang paling sering terjadi lesi adalah bagian medial talus, sedangkan bagian lateral dan posterior lebih jarang. Jika OLT tidak ditangani dengan segera, maka dapat menimbulkan morbiditas pada pasien seperti terganggunya aktivitas sehari-hari.

OLT harus didiagnosa sedini mungkin agar dapat diberikan terapi yang tepat. Jika tidak diterapi, OLT dapat berlanjut menjadi osteroartritis sekunder yang ditandai dengan nyeri serta gangguan fungsi. Pilihan terapi pembedahan menjadi wajib pada pasien usia muda dengan fragmen tulang rawan yang tidak stabil. Pilihan pembedahan diantaranya adalah dengan metode fiksasi, teknik microfractures, atau teknik autologous chondrocyte implantation.

\section{Anatomi Tulang Talus}

Talus adalah salah satu tulang tarsal yang tidak memiliki penempelan otot. Sekitar $60 \%$ permukaan tulang talus tertutup oleh jaringan tulang rawan (cartilage). Bagian badan talus menyangga trochlea pada sisi superior dan kemudian menyempit menjadi prosesus posterior. Prosesus ini menjadi jalan dari tendon otot flexor hallucis longus dan dihimpit oleh tubercle lateralis yang menonjol serta tubercle medialis yang kurang menonjol (gambar 1). ${ }^{4}$

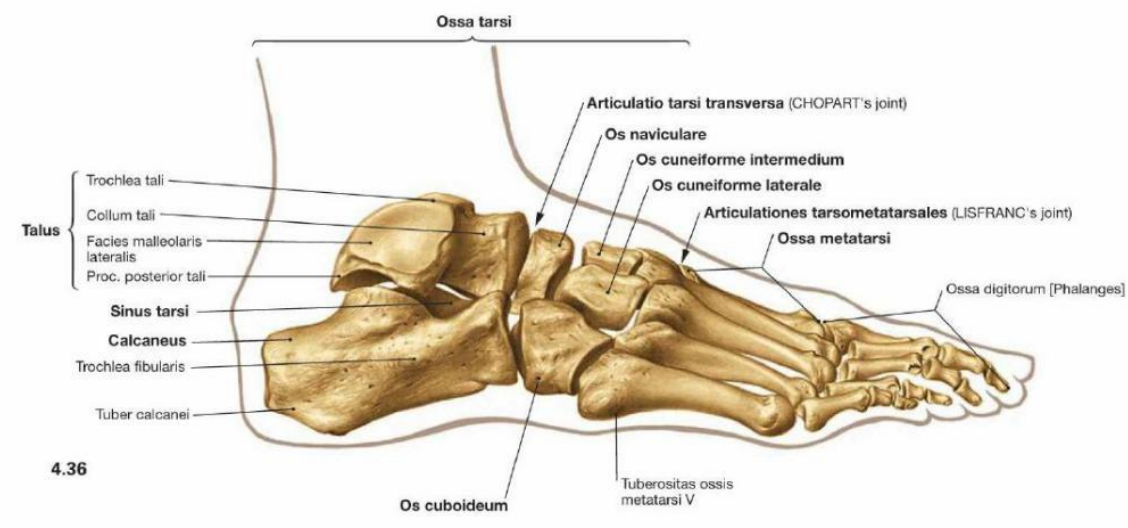

Gambar 1. Anatomi dari pedis, dan posisi tulang talus di dalam kompleks sendi pergelangan kaki. ${ }^{5}$ 
Kubah dari talus tertutup permukaan sendi trochlear yang menyangga beban tubuh. Kubah ini berbentuk trapezoid dan permukaan sisi anterior nya lebih lebar sekitar 2,5 mm dibandingkan sisi posteriornya. ${ }^{6}$ Pada sisi medial talus, terdapat facet yang akan berartikulasi dengan medial malleolus dari tibia. Sedangkan pada sisi lateral nya terdapat facet yang berartikulasi dengan malleolus lateral dari fibula. Permukaan artikuler dari facet-facet ini berhubungan dengan permukaan artikuler superior dari kubah talus (Gambar $2)^{7}$
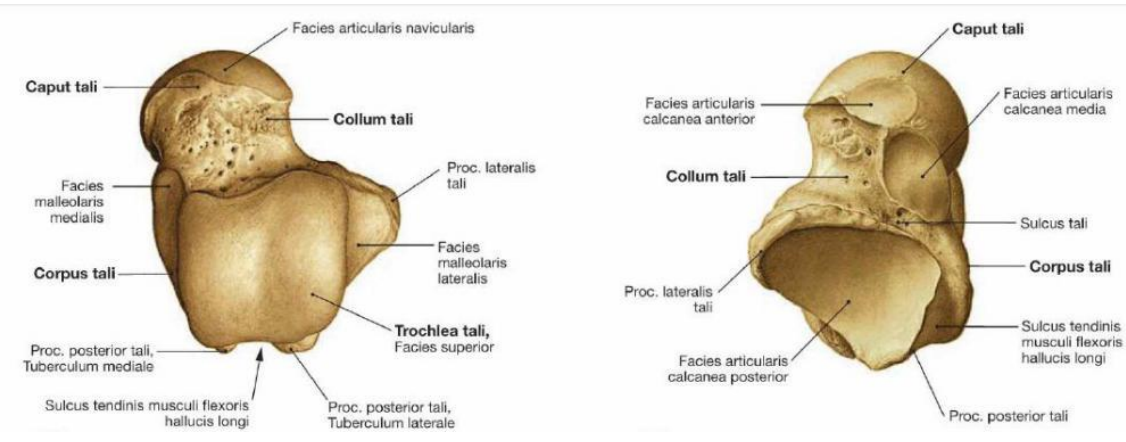

Gambar 3.Anatomi tulang talus. ${ }^{5}$

\section{PATOFISIOLOGI OSTEOCHONDRAL LESION OF THE TALUS \\ Osteochondral Lesion of the Talus Idiopatik}

Lesi osteochondral idiopatik adalah lesi yang bersifat fokal dari subchondral tulang. Lesi ini memiliki resiko terjadinya instabilitas dan gangguan pada tulang rawan artikuler yang berdekatan. ${ }^{8}$ Disfungsi dari tulang subchondral idiopatik diduga disebabkan oleh faktor vaskuler yang disertai dengan osteonekrosis dari subchondral. Hal ini berkontribusi dalam menyebabkan kerusakaan pada tulang rawan yang berada di lapisan atasnya. Gangguan vaskular dapat disebabkan karena trauma mikro berulang atau bisa disebabkan adanya gangguan pada anastomosis pembuluh darah antara tulang rawan dan subchondral dalam masa perkembangan. Namun patofisiolgi mengenai hal ini masih belum diketahui dengan pasti. ${ }^{2}$

\section{Osteochondral Lesion of the Talus Akibat Trauma}

Sebagian besar OLT, termasuk defek osteochondral dan fraktur osteochondral sekunder disebabkan oleh trauma. Sekitar 50\%
OLT disebabkan cedera ankle dan sekitar 73\% dari fraktur ankle dapat berlanjut menjadi cedera pada tulang rawan. OLT yang disebabkan oleh trauma pada sisi lateral lebih sering terjadi dibandingkan sisi medial. Sekitar 94\% OLT lateral disebabkan oleh trauma, sedangkan hanya 62\% OLT medial yang disebabkan oleh trauma. Penyebab trauma pada lateral talar dome adalah beban axial yang dikombinasi dengan inversi dan dorsofleksi. Sedangkan penyebab trauma pada medial talar dome disebabkan oleh beban axial inversi, plantarfleksi, dan rotasi eksternal. ${ }^{1}$

Beberapa penelitian mengenai evaluasi karakteristik anatomi pada OLT, menemukan bahwa sebagian besar lesi ini berlokasi pada zona centromedial dan centrolateral. Studi ini juga menemukan bahwa lesi medial cenderung lebih luas dan dikaitkan dengan perubahan pada lapisan subchondral. Oleh karena itu, muncul kecurigaan adanya faktor lain selain trauma yang menjadi patofisiologi beberapa penyebab lesi medial talar. ${ }^{9}$

Tulang talus dan tulang rawan talus sangat rentan untuk terjadinya lesi osteochondral secara sekunder dikarenakan beberapa karakteristik anatomisnya. Pertama, 60\% dari tulang talus tertutup oleh tulang rawan, dimana 
kapasitas regenerasi intrinsiknya rendah karena anatomisnya yang avaskuler. ${ }^{2}$ Oleh karena itu, nutrisi tulang rawan sangat bergantung dari cairan sinovial dan dari lapisan subchondral. ${ }^{10}$ Fakta bahwa suplai vaskuler dari tulang talus yang kurang, menyebabkan semakin berkurangnya kemampuan tulang rawan talus untuk sembuh setelah terjadi trauma. Suplai vaskuler tulang talus berasal dari jaringan kompleks anastomosis peronal, tibialis posterior dan tibialis anterior. Anastomosis ini mengakibatkan area tulang talus menjadi area perbatasan yang miskin vaskuler. Area ini juga bersifat retrograde sehinga membuat tulang talus sulit sembuh dari cedera. Kedua, tulang rawan talus relatif lebih tipis bila dibandingkan dengan sendi penanggung beban tubuh lainnya di ektremitas bawah. Sheperd dan Seedhom menunjukkan bahwa ketebalan tulang rawan pada ankle kadaver secara statistik lebih tipis signifikan bila dibandingkan sendi lutut dan panggul. Mereka menemukan bahwa ketebalan pada sendi ankle $0,7 \mathrm{~mm}$ sampai $1,2 \mathrm{~mm}$ dibandingkan dengan 1,5 mm sampai 2,6 mm pada sendi lutut. Semua faktor-faktor ini menjadikan talus sangat rentan untuk terbentuknya lesi osteochondral. ${ }^{11}$

\section{Manifestasi Klinis dan Pemeriksaan Fisik Osteochondral Lesion of the Talus}

Manifestasi klinis pasien OLT bervariasi tergantung dari berbagai faktor termasuk penyebab dari lesinya. Keluhan yang paling sering dirasakan pasien adalah nyeri, bengkak, dan kekakuan pada sendi ankle. Keluhan ini akan dirasakan semakin memberat dengan aktivitas seperti menahan beban (weightbearing). ${ }^{3}$ Namun keluhan-keluhan ini tidak spesifik karena bisa ditemukan pada penyakit sendi lainnya. Oleh karena itu, dokter harus dapat menduga lesi ini sebagai diagnosa awal pada pasien dengan keluhan di atas, dengan tetap mempertimbangkan diagnosis banding lainnya, seperti fraktur tersembunyi, hindfoot coalitions atau deformity, syndesmotic injury, instabilitas lateral ankle, peroneal tendonopathy, impingement dan arthritis ankle atau subtalar. ${ }^{12}$

Ketika ada kecurigaan ke arah OLT, pasien harus ditelusuri apakah ada riwayat trauma pada ankle. Pemeriksaan fisik yang dapat ditemukan pada pasien adalah efusi, range of movement yang berkurang, serta nyeri bila dilakukan palpasi, inversi atau dorsofleksi. Tes provokasi termasuk anterior drawer dan talar tilt sebaiknya dilakukan, dan semua pemeriksaan harus dibandingkan dengan sisi kontralateral. ${ }^{13}$

\section{Pemeriksaan Radiologis Osteochondral Lesion of the Talus}

Pemeriksaan radiologis lini pertama yang disarankan adalah pemeriksaan X-Ray sisi AP, Lateral dan Mortise. Berndt dan Haety mendeskripsikan klasifikasi pertama dari OLT berdasarkan gambaran radiologisnya. Pada klasifikasi tersebut dinyatakan bahwa tahap 1 adalah area kecil berupa kompresi subchondral, tahap II adanya bagian osteochondral yang terpisah sebagian, tahap III bagian osteochondral telah terpisah seluruhnya namun tanpa adanya displacement, sedangkan pada tahap IV bagian osteochondral telah terpisah seluruhnya dan terjadi displacement ${ }^{14}$ (gambar $3)$.
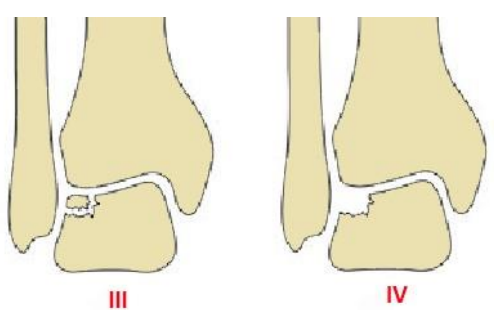

Gambar 4. Klasifikasi OLT dari Berndt dan Harty. ${ }^{14}$ 
Jika dengan pemeriksaan radiografi sederhana menunjukkan hasil yang negatif namun kecurigaan ke arah lesi masih ada, maka dapat dilakukan pemeriksaan radiografis yang lebih canggih seperti MRI dan CT scan. Setiap pemeriksaan ini memiliki kelebihan dan kekurangan masing - masing dalam pemeriksaan OLT. Namun di antara kedua pemeriksaan ini, MRI memiliki angka sensitivitas yang lebih tinggi dalam menemukan adanya gambaran lesi bila dibandingkan dengan CT Scan, dengan angka sensitivitas MRI 96\% dan CT Scan $81 \%$. MRI memberikan visualisasi permukaan artikuler dan jaringan lunak yang sangat baik, dimana hal ini sangat membantu untuk mendeteksi karakterisasi OLT. ${ }^{15}$ Namun bila didapatkan edema pada klinisnya, dapat terjadi estimasi berlebihan dari ukuran lesi atau sulitnya melalukan penilaian dari kondisi tulang sesungguhnya serta ukuran dimensi yang tepat dari lesi osteochondral. Sebaliknya, CT Scan dapat memberikan gambaran yang lebih baik untuk kondisi tulang subchondral dan dimensi maupun lokasi dari kista subchondral. Karena pentingnya pemeriksaan ini dalam menentukan terapi yang sesuai, maka CT scan sangat membantu untuk perencanaan preoperatif dan menjadi pilihan ketika pemeriksaan X-Ray menunjukkan adanya lesi osteochondral yang memerlukan terapi operatif. Diperlukan pendekatan yang spesifik untuk setiap pasien, ketika memilih modalitas radiologis yang canggih untuk mendeteksi, mengevaluasi dan menentukan pilihan terapi OLT. ${ }^{16}$

Sistem klasifikasi berdasarkan pemeriksaan radiologis canggih ada lebih dari satu. Semua klasifikasi ini penting dari sisi historis dan menjadikan deskripsi klasifikasi lesi menjadi lebih seragam. Namun manfaat klasifikasi dalam menentukan terapi jarang digunakan. Pengklasifikasian ini tidak menggunakan ukuran lesi sebagai acuan. Sedangkan ukuran lesi adalah salah satu faktor penting dalam menentukan terapi yang sesuai karena dikaitkan dengan hasil klinis akhir. Pengklasifikasian OLT lain diantaranya adalah klasifikasi oleh Hepple et al dan Ferkel et al. Hepple et al mengembangkan sistem klasifikasi berdasarkan MRI pada tahun 1999. ${ }^{17}$ Sedangkan Ferkel et al mengembangkan sistem klasifikasi berdasarkan CT scan pada tahun $1990 .^{18}$

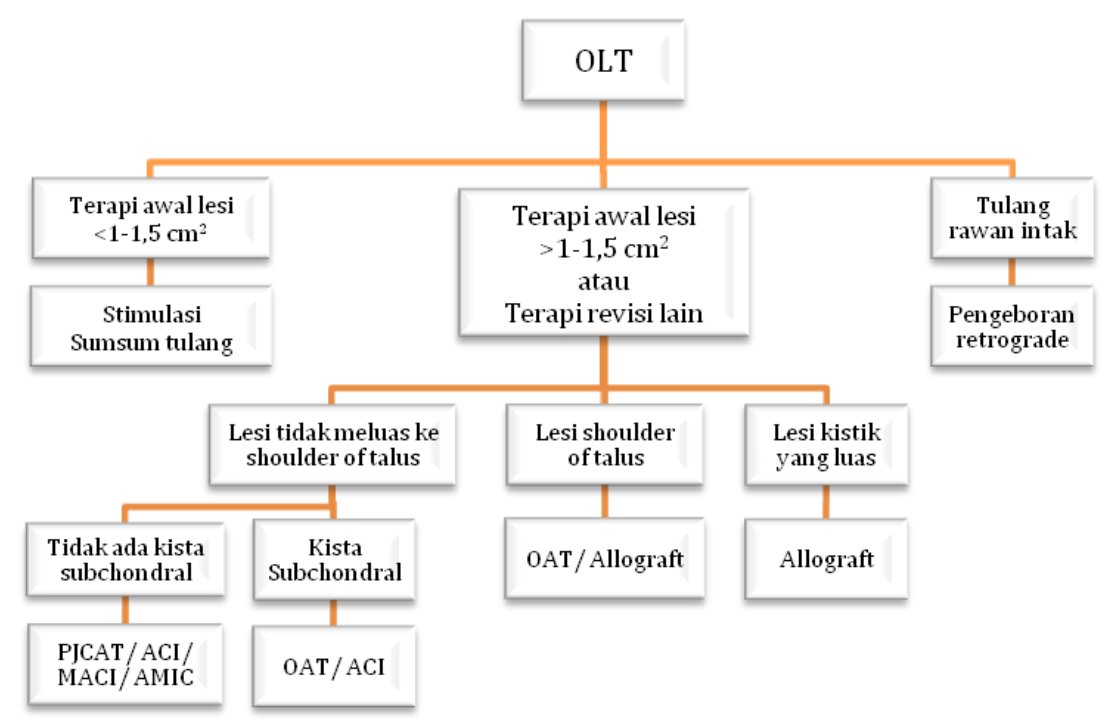

Gambar 5. Algroitma terapi Osteochondral lession of the Talus (OLT). Autologous Matrix-Induced Chondrogenesis (AMIC); Matrix-induced Autologous Chondrocyte Implantation (MACI); Osteochondral Allograft Transplantation; (OAT); Particulated Juvenile Cartilage Allograft Transplantation (PJCAT) ${ }^{1}$ 
microfraktur. Berdasarkan studi tersebut, pada lesi dengan ukuran diameter rata-rata kurang dari $15 \mathrm{~mm}$ tidak didapatkan terapi yang gagal, namun pada lesi dengan ukuran lebih dari 15 $\mathrm{mm}$, didapatkan 1 pasien yang terapinya gagal. Studi kolaboratif dari Choi et al melaporkan keberhasilan dari terapi ini jika ukuran lesi kurang dari $150 \mathrm{~mm}^{2}$ berdasarkan pemeriksaan radiologis MRI. Terapi operatif mikrofraktur menjadi pilihan utama pada OLT dengan ukuran kurang dari $150 \mathrm{~mm}^{2} .^{20}$
Lesi OLT kronis atau lesi yang berhubungan dengan arthritis ankle dan diterapi dengan teknik operatif microfraktur, tidak memberikan kemajuan dalam perbaikan keluhan bila dibandingkan dengan lesi OLT akut atau yang terisolasi. Dari beberapa studi, tidak ditemukan hubungan antara usia pasien atau lokasi dari lesi, baik medial maupun lateral, dengan hasil perbaikan klinis. ${ }^{21}$
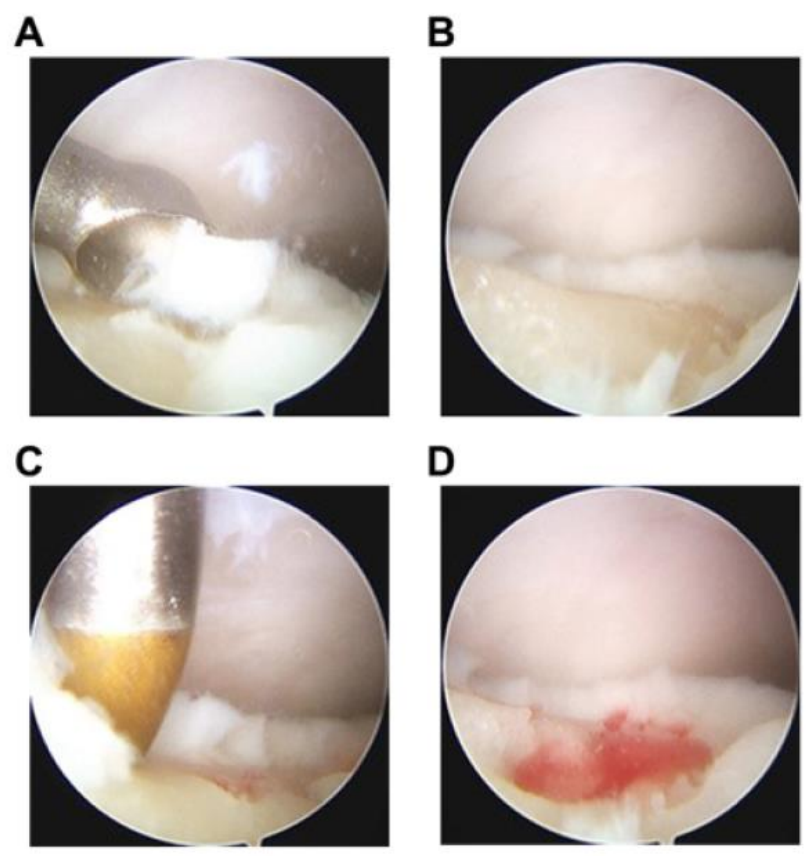

Gambar 6. Tehnik Mikrofraktur, (A, B) Debridement dari medial talar dome OLT untuk menstabilkan pinggir lesi. (C) Mikrofraktur dilakukan. (D) Element dari sumsum tulang terlihat keluar dari perforasi hasil mikrofraktur. ${ }^{1}$

\section{Regenerasi Tulang Rawan (Cartilage Regeneration)}

Terapi operatif regenerasi tulang rawan adalah terapi dengan menggunakan autologous chondrocyte implantation (ACI), matrixinduced autologous chondrocyte implantation (MACI), dan transplantasi sel derivat sumsum tulang. Teknik ini biasa dilakukan bila terapi operatif microfracture tidak berhasil atau pada kasus OLT dengan lesi yang lebih besar sehingga tidak dapat diterapi dengan microfracture. ACI adalah prosedur dengan 2 tahap (gambar 9). Tahap pertama, tulang rawan hyaline diambil dari sisi anterior dari talus atau bagian yang non-weightbearing dari lutut. Tulang rawan ini kemudian dikultur untuk menumbuhkan kondrosit yang dapat dipakai setidaknya sepanjang 1 tahun. Tahap kedua, kondrosit yang didapat dari hasil kultur akan ditanamkan pada lesi osteochondral dengan cara dijahit. Hal ini didasarkan pada pemikiran bahwa kondrosit memiliki kemampuan untuk regenerasi tulang rawan hyaline baru yang dapat mengisi dan menutupi lesi pada osteochondral. ${ }^{22}$ 
Beberapa studi melaporkan hasil yang baik dengan terapi ACI. Terapi ACI lebih dipilih pada lesi yang fokal dengan kondisi kerangka tulang rawan yang stabil. Terapi ACI juga merupakan pilihan untuk ukuran lesi yang lebih besar dari 1-1,5 $\mathrm{cm}^{2}$.
A

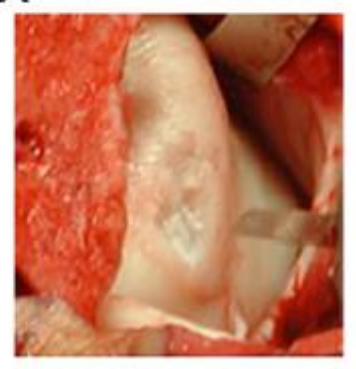

C

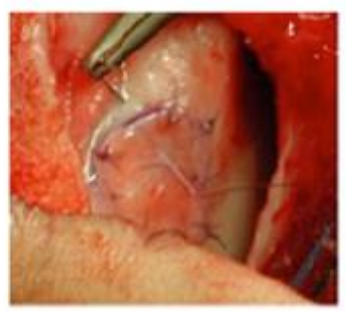

B

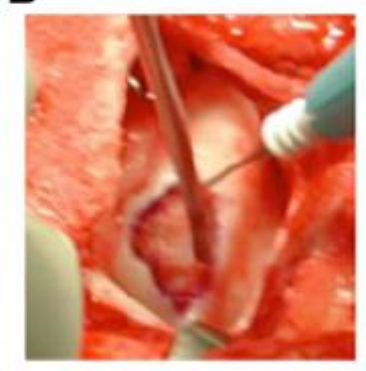

D

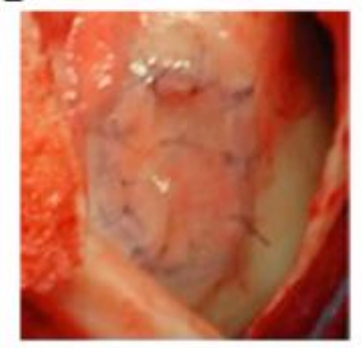

Gambar 7. Autologous chondrocyte implantation (ACI). (A) Osteochondral lesion of the talus (OLT), Osteotomi dilakukan. (B) OLT dilakukan debridement dan kondrosit ditanam. (C) Potongan periosteal dijahit di atas ACI. (D) Pemberian lem fibrin menutupi ACI. ${ }^{1}$

Generasi kedua terapi ini adalah matrix autologous chondrocyte implantation (MACI) yaitu terapi yang menggunakan scaffold daripada dengan menggunakan potongan periosteal untuk menutup implan kondrosit. Terapi ini tetap menggunakan 2 tahap prosedur, namun dengan penggunaan matriks selular, maka waktu operatif yang dibutuhkan dan morbiditas menjadi berkurang. Selain itu, distribusi kondrosit di area lesi juga menjadi lebih merata. Berdasarkan studi meta-analisis, hasil akhir dari terapi MACI juga memberikan hasil terapi yang baik dengan angka keberhasilan 89\% dan hasil second-look dari arthroscopy menunjukkan adanya penyembuhan permukaan artikuler. Hasil MRI setelah operasi menunjukkan lebih banyak jaringan tulang rawan yang normal bila dibandingkan dengan pasien yang mendapat terapi microfracture..$^{23}$

\section{Penggantian Tulang Rawan (Cartilage Replacement)}

Terapi operatif penggantian tulang rawan diantaranya adalah Osteochondral autograft transfer (OAT), osteochondral allograft dan particulated juvenile cartilage allograft transplantation (PJCAT). Terapi ini dipilih jika lesi lebih besar dari $1-1,5 \mathrm{~cm} 2$ dan terletak di bahu talus atau lesi dengan batasbatas lesi yang tidak stabil. Teknik OAT mengganti lesi ostechondral talus dengan tulang rawan hyaline yang diambil dari talus pasien atau bagian non-weightbearing dari lutut (gambar 7). Keuntungan dari prosedur ini adalah graft yang diimplan tetap mempertahankan kolagen tipe II, sehingga dalam proses penyembuhan, lebih banyak tulang rawan normal yang menutupi lesi. Hal ini tetap berlaku pada lesi dengan luas lebih besar dari 3,5 
$\mathrm{cm}^{2}{ }^{23}$ Beberapa studi melaporkan hasil yang memuaskan dengan berkurangnya nyeri dan meningkatnya fungsionalitas pasien dengan menggunakan prosedur ini. Kelemahan terbesar dari prosedur ini adalah adanya kemungkinan terjadi morbiditas dari lokasi donor graft yang diambil. ${ }^{24}$

Tindakan operatif Osteochondral allograft transplantation (OAT) dikerjakan sebagai pilihan terapi jika terdapat lesi dengan luka yang luas. OAT bisa menggunakan allograft plugs, autograft plugs, atau menggunakan bulk allograft. Teknik ini menggunakan freshfrozen graft yang diambil dari kadaver manusia oleh bank jaringan yang terlisensi. Fresh graft memberikan hasil viabilitas kondrosit yang meningkat dan lebih sedikit terjadinya cartilage breakdown bila dibandingkan dengan fresh-frozen graft, sehingga fresh graft dianggap lebih superior dibandingkan fresh-frozen graft. $^{25}$ Ukuran allograft dari pendonor disesuai dengan lesi dari resipien dengan menggunakan CT scan. Terapi ini bisa diberikan pada pasien dengan lesi kistik yang besar dan memiliki kelebihan dapat menyembuhkan kehilangan tulang rawan di multi dimensi. Selain itu, tidak didapatkan morbiditas dari situs pendonor walaupun allograft yang diambil luas. Dari beberapa studi menunjukkan, teknik ini memberikan hasil yang baik dengan hasil akhir meningkatnya fungsionalitas dan kepuasan pasien yang mengalami lesi seluas $6 \mathrm{~cm}^{2} .^{26}$ Namun, komplikasi seperti resorpsi, collapse, nonunion dan graft yang tidak stabil adalah hal yang umum terjadi dengan tingkat arthrodesis 13 hingga $33 \%$ pada beberapa kasus serial. ${ }^{27}$
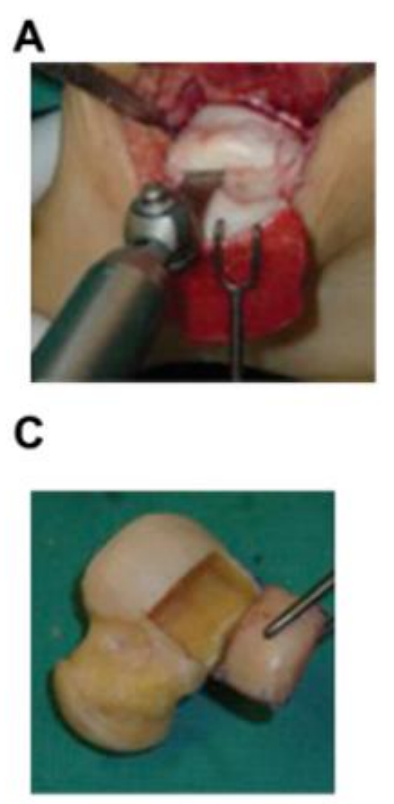

B

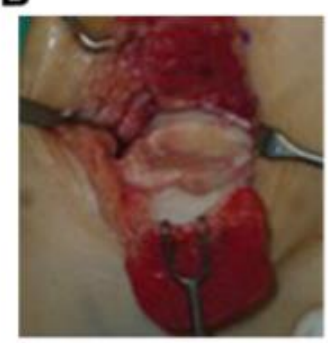

D

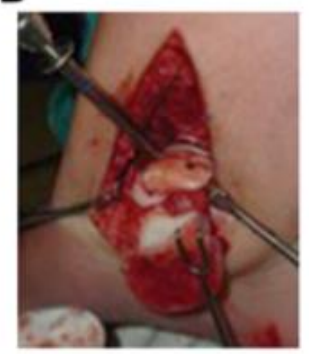

Gambar 8. Osteochondral allograft transplantation (OAT). (A) Eksisi dari lesi pada shoulder of talar (osteotomi dilakukan). (B) Lesi pada talus diangkat. (C) Allograft donor dengan graft yang akan diimplan, diangkat. (D) Graft dilakukan fiksasi menggunakan 2 screw. ${ }^{1}$

Tehnik PJCAT dilakukan dengan transplantasi potongan segar dari tulang rawan remaja yang berisi sel-sel hidup di dalam extra seluler matriks (gambar 8). Tulang rawan didapat dari donor yang telah meninggal dengan rentang usia bayi baru lahir hingga remaja usia 13 tahun. Karena sifat khusus dari allograft, teknik ini dapat dilakukan dengan pendekatan 
teknik operasi yang lebih kecil dibandingkan graft osteochondral. Dengan demikian tindakan osteotomy tidak perlu dilakukan, bahkan teknik PJCAT dapat dilakukan melalui prosedur arthroscopy. ${ }^{28}$ Graft yang telah diimplan pada lesi osteochondral difiksasi dengan menggunakan lem fibrin dalam prosedur satu tahap sehingga mengurangi angka morbiditas pada situs pendonor. Kekurangan dari teknik PJCAT adalah terbatasnya suplai allograft, resiko terjadinya transmisi penyakit secara teoritis, dan kurangnya data penelitian jangka panjang. ${ }^{1}$

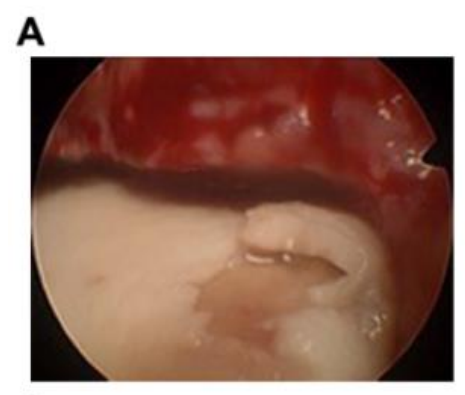

B
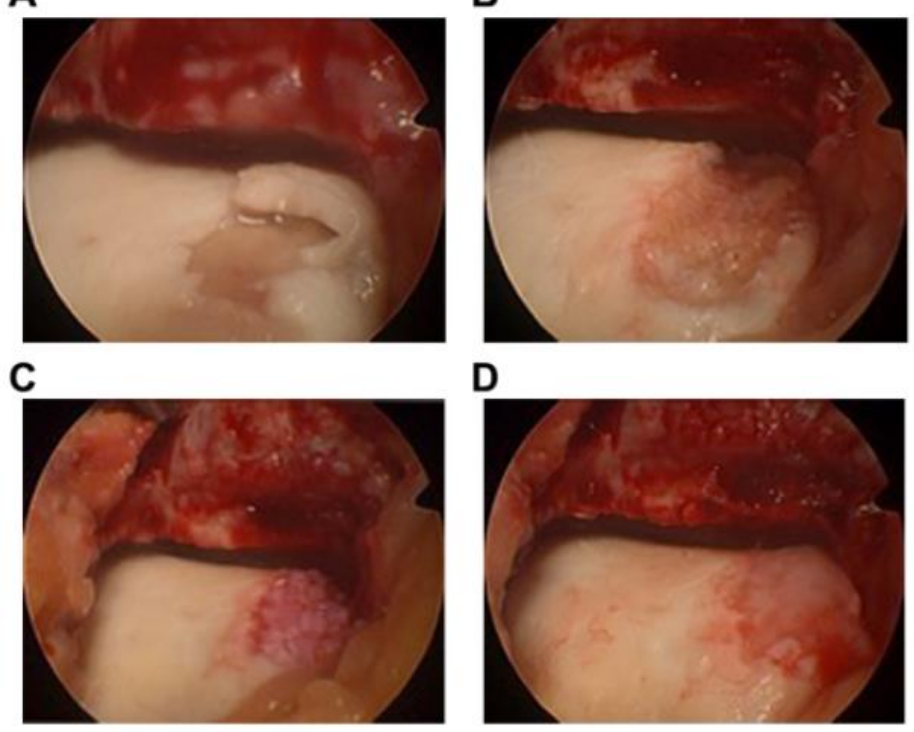

Gambar 9. Particulated Juvenile Cartilage Allograft Transplantation (PJCAT). (A) OLT pada isi medial yang tidak stabil. (B) Debridement pada lesi hingga pinggir lesi yang stabil. (C) Potongan allograft diimplan pada dasar lesi. (D) Potongan tulang rawan ditutup dengan lem fibrin. ${ }^{1}$

\section{KESIMPULAN}

Patofisiologi penyakit Osteochondral lesions of the talus meliputi berbagai macam penyebab yang dapat mengakibatkan morbiditas yang bermakna pada pasien. Salah satu penyebab yang paling sering terjadi adalah lesi yang disebabkan oleh trauma. Namun demikian, OLT juga dapat terjadi disebabkan oleh faktor-faktor non-trauma. Pasien biasanya datang berobat ke tenaga kesehatan dengan keluhan yang tidak spesifik dan dengan gejala seperti nyeri pada pergelangan kaki, bengkak, berkurangnya ruang gerak. Oleh karena itu, praktisi klinis harus selalu curiga adanya lesi osteochondral ketika ada keluhan seperti yang disebutkan di atas dan dapat menentukan pemeriksaan penunjang radiologis yang tepat. Nondisplaced OLT lebih sering diberikan terapi konservatif dengan mengurangi weightbearing. Namun demikian sebagian besar masih tetap memiliki keluhan gejala dan memerlukan tindakan operatif. Ada beberapa macam tehnik operatif yang dapat dilakukan untuk menyembuhkan OLT. Tehnik operatif ini dapat dikategorikan menjadi cartilage repair, cartilage regeneration dan cartilage replacement techniques. Studi menunjukkan hasil yang menjanjikan dengan berkurangnya keluhan dengan tindakan-tindakan operatif ini.

Kurangnya studi komparatif yang berkaitan dengan terapi untuk OTL, maka tidak ada kriteria yang spesifik yang dapat 
disarankan untuk bedah orthopaedi sebagai terapi lini pertama. Oleh karena itu setiap terapi yang dipilih harus disesuaikan dengan skill dari operator dan faktor-faktor pasien secara individual. Studi lebih lanjut diperlukan untuk menentukan pilihan terapi yang lebih superior dan lebih spesifik yang terarah untuk setiap pasien dan jenis lesi yang diderita.

\section{REFERENSI}

1. Steele JR, Dekker TJ, Federer AE, Liles JL, Adams SB, Easley ME. Osteochondral lesions of the talus: current concepts in diagnosis and treatment. Foot Ankle Orthop. 2018;3(3):1-9.

2. Zanon G, Vico GD, Marullo M. Osteochondritis dissecans of the talus. Joints. 2014;2(3):115-23.

3. Laffenetre O. Osteochondral lesions of the talus: current concept. Orthop Traumatol Surg Res. 2010;96(5):554-566.

4. Hertel J. Functional anatomy, pathomechanics, and pathophysiology of lateral ankle instability. $J$ Athl Train. 2002;37(4):364-375.

5. Paulsen F dan Wascke. Sobota Atlas Anatomi. Jilid 1 Edisi 23. 2010

6. Rungprai C, Tennant JN. Gentry RD, Phisitkul P. Management of osteochondral lesions of the talar dome. Open Orthop J. 2017;11:743-61.

7. Sugimoto K, Takakura Y, Tohno Y, Kumai T, Kawate K, Kadono K. Cartilage thickness of the talar dome. Arthrosc - J Arthrosc Relat Surg. 2005;21(4):401-404.

8. Prasarn ML, Miller AN, Dyke JP, Helfet DL, Lorich DG. Arterial anatomy of the talus: a cadaver and gadolinium-enhanced MRI study. Foot Ankle Int. 2010;31(11):987-993.

9. Elias I, Carrino JA, Raikin SM, Jung JW, Schweitzer MW, Morrison WB. Osteochondral lesions of the talus: change in mri findings over time in talar lesions without operative intervention and implications for staging systems. Foot Ankle Int. 2017;27(3):157-166.

10. Wang Y, Wei L, Zeng L, He D, Wei X.
Nutrition and degeneration of articular cartilage. Knee Surgery Sport Traumatol Arthrosc. 2012;21(8):1751-1762.

11. Shepherd DET, Seedhom BB. Thickness of human articular cartilage in joints of the lower limb. Ann Rheum Dis. 1999;58(1):27-34.

12. Alazzawi S, Sukeik M, King D, Vemulapalli K. Foot and ankle history and clinical examination: A guide to everyday practice. World J Orthop. 2017;8(1):2129.

13. Bahr R, Pena F, Shine J, Lew WD, Lindquist C, Tyrdal S, et al. Mechanics of the anterior drawer and talar tilt tests : A cadaveric study of lateral ligament injuries of the ankle Mechanics of the anterior drawer and talar tilt tests A cadaveric study of lateral ligament injuries of the ankle. Acta Orthop Scand. 2009;68(5):435-441.

14. Seo SG, Kim JS, Seo DK, Kim YK, Lee $\mathrm{SH}$, Lee HS. Osteochondral lesions of the talus. Acta Orthop. 2018;89(4):462-467.

15. Posadzy M, Desimpel J, Vanhoenacker F. Staging of Osteochondral Lesions of the Talus: MRI and Cone Beam CT. J Belg Soc Radiol. 2017;101(2):1-7.

16. Kirschke JS, Braun S, Baum T, Holwein $C$, Schaeffeler C, Imhoff AB, et al. Diagnostic Value of CT Arthrography for Evaluation of Osteochondral Lesions at the Ankle. Biomed Research Int. 2016;2016:12-16.

17. Hepple S, Winson IG, Glew D, R FRC. Osteochondral Lesions of the Talus: A Revised Classification. Foot Ankle Int. 1999;20(12);789-793.

18. Ferkel RD, Zanotti RM, Komenda GA, Sgaglione NA, Cheng MS, Applegate GR, et al. Arthroscopic treatment of chronic osteochondral lesions of the talus: longterm results. Am J Sports Med. 2008;36(9):1750-1762.

19. Chuckpaiwong B, Berkson EM, Theodore GH. Microfracture for Osteochondral Lesions of the Ankle: Outcome Analysis and Outcome Predictors of 105 Cases. Athroscopy. 2008;24(1):106-112. 
20. Choi WJ, Park KK, Kim BS, Lee JW.

Osteochondral lesion of the talus: is there a critical defect size for poor outcome?. Am J Sports Med. 2009;37(10):19741980.

21. Choi WJ, Kim BS, Lee JW. Osteochondral lesion of the talus: could age be an indication for arthroscopic treatment?. Am J Sports Med. 2012;40(2):419-424.

22. Mitchell ME, Giza E, Sullivan MR. Cartilage transplantation techniques for talar cartilage lesions. Journal Am Acad Orthop Surg. 2009;17(7):407-414.

23. Magnan B, Samaila E, Bondi M, Vecchini E, Micheloni GM, Bartolozzi P. Chondrocytes implantation for osteochondral lesions of the talus: midterm results. Adv Orthop. 2012;2012:28-30.

24. Gobbi A, Francisco RA, Lubowitz JH, Allegra F, Canata G. Osteochondral lesions of the talus: randomized controlled trial comparing chondroplasty, microfracture, and osteochondral autograft transplantation. Randomized Controlled Trial. 2006;22(10):1085-1092.

25. Sammarco GJ, Makwana NK. Treatment of talar osteochondral lesions using local osteochondral graft. Foot Ankle Int. 2002;23(8):693-698.

26. Enneking WF, Campanacci DA. Retrieved human allografts: a clinicopathological study. JBJS. 2001;83(7):971-986.

27. Dean CS, Chahla J, Serra Cruz R, LaPrade RF. Fresh osteochondral allograft transplantation for treatment of articular cartilage defects of the knee. Arthrosc Tech. 2016;5(1):157-161.

28. Gross AE, Agnidis Z, Hutchison CR. Osteochondral defects of the talus treated with fresh osteochondral allograft transplantation. Foot Ankle Int. 2001;22(5):385-391.

29. Adams SB, Demetracopoulos CA, Parekh SG, Easley ME, Robbins J. Arthroscopic particulated juvenile cartilage allograft transplantation for the treatment of osteochondral lesions ofthe talus. 